\author{
Olga Vlasenko \\ PhD in Economics, Associate Professor of Economics and Finance Department \\ Odessa National Maritime University, Odessa, Ukraine \\ E-mail: olga.vlasenko.mail@gmail.com \\ ORCID: https://orcid.org/0000-0001-9669-4438 \\ ResearcherID: AAJ-1028-2021 \\ Mariia Sokolova \\ Applicant for Higher Education Degree, Department of Economics and Finance \\ Odessa National Maritime University, Odessa, Ukraine \\ E-mail: maria.83sokolova@gmail.com \\ ORCID: https://orcid.org/0000-0002-3734-4005
}

\title{
Evaluation of enterprise human resources: the theory background
}

\begin{abstract}
This article is devoted to the peculiarities of human resources evaluation in enterprises. The human resources evaluation has a special place in human resource management, because it allows you to identify the actual situation in an enterprise, find disadvantages and weaknesses in management, so that you can provide recommendations basing on its results. The main purpose of the study was to develop the theoretical principles for assessing human resources, which should establish the level of quantitative and qualitative characteristics in the terms of determining the state of motivation and efficiency for human resources. In the study, the authors stressed on the cyclical nature of human resource management in an enterprise. At the same time, in their opinion, the human resources evaluation takes a special place because it makes all actions passing through the human resources management system. The authors also stressed on the impact of motivation upon an enterprise efficient operation, and including but not limiting to the human resources. They found that motivation has a special relevance for human resource management, and thus is gained by solving such problems as coordination, matching up of the needs and means, motives and goals of human resources and an enterprise as a whole, identification and resolution of emerging contradictions between these goals and needs of human resources and an enterprise. Solving these problems is possible after a comprehensive evaluation of an enterprise's human resources. The authors propose to conduct a comprehensive evaluation in clearly defined areas: quantitative and qualitative evaluation, evaluation of the motivational state of human resources, and the final stage is to evaluate the efficiency of using Enterprise Human Resources. In the result of such evaluation, the administrative goal of human resource management will be achieved due to adoption of sound administrative decisions; thus, the information goal will be achieved as well, which is that both employees and managers have the opportunity to obtain reliable information about the activities; of course, the motivational goal of evaluation itself is among the most important means of motivating people's behaviour. In the authors' opinion, their proposed theoretical approach to the evaluation of human resources, which is implemented due to identifying the level of quantitative and qualitative characteristics of human resources' motivation and efficiency, will lead to conscious human resource management.
\end{abstract}

DOI: https://doi.org/10.30525/2500-946X/2021-1-6

\section{Statement of the problem}

Human resources are the main resources at the present stage of business and economy development in various industries. At the same time, the requirements for firm employees are radically changing. Unfortunately, as it has turned out, many enterprises were not ready for such challenge. Unfortunately, many managers share the simplistic idea that the transition to new technologies would solve all or most of business problems. However, this is just one more misconception that only technical and technological conditions affect efficiency of an enterprise's activities. Such managers ignore the impact of human resources on quality business activities. At the same time, the attempts of individual managers to introduce new

\author{
Keywords \\ Human resources, complex \\ evaluation, human resources \\ evaluation, human resource \\ management, motivation, \\ efficiency
}

JEL: D24, J24, J53, L25, M54 enterprise management technologies are limited only to creation of departments with new names, and sometimes with some new functions. However, the real results of such changes are either not noticeable, or do not reach the expected level. Therefore, managers still prefer development only in the areas of modern equipment and technologies use, and do not use the opportunity to develop human resources.

Recent radical economic transformations and dynamic innovation processes, which are being observed, induce deep interest to the world experience of human resources activation in order to achieve business efficiency and raise competitiveness both in science and in practice. The analysis of this experience confirms that the leading companies' success in the developed countries is associated with the developing highly effective mechanisms for human resource 
management at the enterprise level, based on which there is developed a comprehensive, strategic approach to the use for evaluation and development of human resources.

\section{Latest scientific progress and publications review}

The human resources evaluation takes a special place in human resource management, because it allows defining the real situation in an enterprise (i.e. identifying weaknesses in human resource management), and allows giving recommendations based on its results. Research on theory and practice of human resource management issues is covered in works of many foreign scientists, such as Armstrong M. [1], Björkman I. [21], Dessler G. [9], Drucker P. [10], Kossek E. [14], Koster F. [15], Minbaeva D. [21], Park H. [21], Pedersen T. [21], Fey C. [21], Schuler R. [24], Jackson S. [24], and Ukrainian scientists Vlasenko O. [28], Gavkalova N. [11], Gholovko D. [22], Yevtu-shenko A. [16], Kolot A. [13], Lely Y. [18], Lisak V. [19], Nachar'jan M. [22], Nachar'jan M. [11], Chervinsjka L. [5], Shevchenko O. [25], and others. The evaluation of personnel and human resources was investigated in the works of such foreign scientists: Bratton J. [3], Cascio W. [4], Dessler G. [8], Gold J. [3], Martin J. [20], Papšienè P. [27], Vveinhardt J. [27]. Among Ukrainian scientists who studied similar issues, we can note Balabanova L. [2], who considers evaluation as a purposeful process of establishing the conformity of qualitative characteristics to job or workplace instructions; Vlasenko O. and Sokolova M. [28] who consider human resources evaluation and development through the prism of innovation; Hrishnova O. and Naumova O. [12], who offer modern innovative approaches to staff evaluation using performance and efficiency indicators; Danyliuk I. [7], who studies the principles and methods of personnel evaluation systems, their types and elements; Kolot A. [13] who determines the extent to which each employee achieves the expected results of work and meets the requirements arising from his production tasks; Krushel'nyts'ka O. [16], who determines the tools of the personnel evaluation system and identifies a system of evaluation methods; Savchenko V. [23], who determines that staff appraisal is a procedure provided to identify the degree of compliance of professional, business and personal qualities of the employee, quantitative and qualitative results of his work to certain requirements; Chevhanova V. [6], who lists the main components of the personnel evaluation system and considers the most common methods of personnel evaluation.

\section{The purpose and problem of research}

From the foregoing analysis of the problem, it appears that there is a need to define the current features of human resources evaluation. Therefore, the main purpose of the study is to develop theoretical foundations for the human resources evaluation, which should establish the level of quantitative and qualitative characteristics in the terms of determining the state of motivation and efficiency for human resources use.

\section{Results of the research}

In our opinion, more business leaders should realize that competitive advantage is, above all, the advantage of their own human resources over the competitors' human resources.

In modern economics, the following production factors are identified: capital, natural resources, labour, entrepreneurial skills, and information. Obviously, the same instruments and subjects of labour are available to all market participants at the same terms. The human resources are the only important factor in the complete technological cycle system.

Human resource management as a management process has a cyclical nature (Figure 1), which begins with planning, and ends this with analysis and control. The cyclical nature is manifested not only in the sequence of management functions realization, but in performing specific actions as well. At the same time, the human resources evaluation occupies a special position, because it connects all actions within the human resources management system. Improving the human resource management quality begins with their evaluation.

The sense of firm's human resources evaluation becomes clear only in the context of the personnel policy, which is implemented by an enterprise. A comprehensive, strategic approach to the human resources use, evaluation, and development is the basis for development of the effective mechanism for firm human resources management. In our opinion, motivation, which has an impact on enterprises' efficiency and human resources as well, is the main component of such a mechanism.

Therefore, motivation acquires special urgency for human resources management in the view of the necessity to solve coordination problems, matching up of the needs and means, define the motives and purpose of human resources and the enterprise as a whole, define and solve arising contradictions between the purposes and needs of human resources and the enterprise as whole. In turn, introducing the motivation as an efficient instrument requires constant self-improvement, systematic training, responsibility, determination, initiative, creative activity in terms of strict regulation of working hours.

We can highlight the most important evaluation goals:

- review of past work performance;

- improving current performance;

- setting future goals for work;

- identifying and evaluating the needs in professional training and development;

- evaluation of possibility for changing remuneration of labour.

The administrative goal is also achieved due to the adoption of a reasonable administrative decision (promotion or demotion, transfer to another job, training assignment, dismissal) based on the results of evaluation of human resources. It is important to remember about achieving the information goal, which is to ensure that both employees and managers obtain reliable information about an enterprise's activities. Such information is extremely important for an employee in terms of improving one's activities, and gives managers opportunities to make the right management decisions. Of course, the motivational goal is achieved, which is to ensure that evaluation itself is the most important instrument to motivate people's behaviour, as adequately estimated labour costs will provide further growth in employees' productivity, but only if an employee's work is evaluated according to expectations.

The main tasks of human resources evaluation in enterprises include the following: 


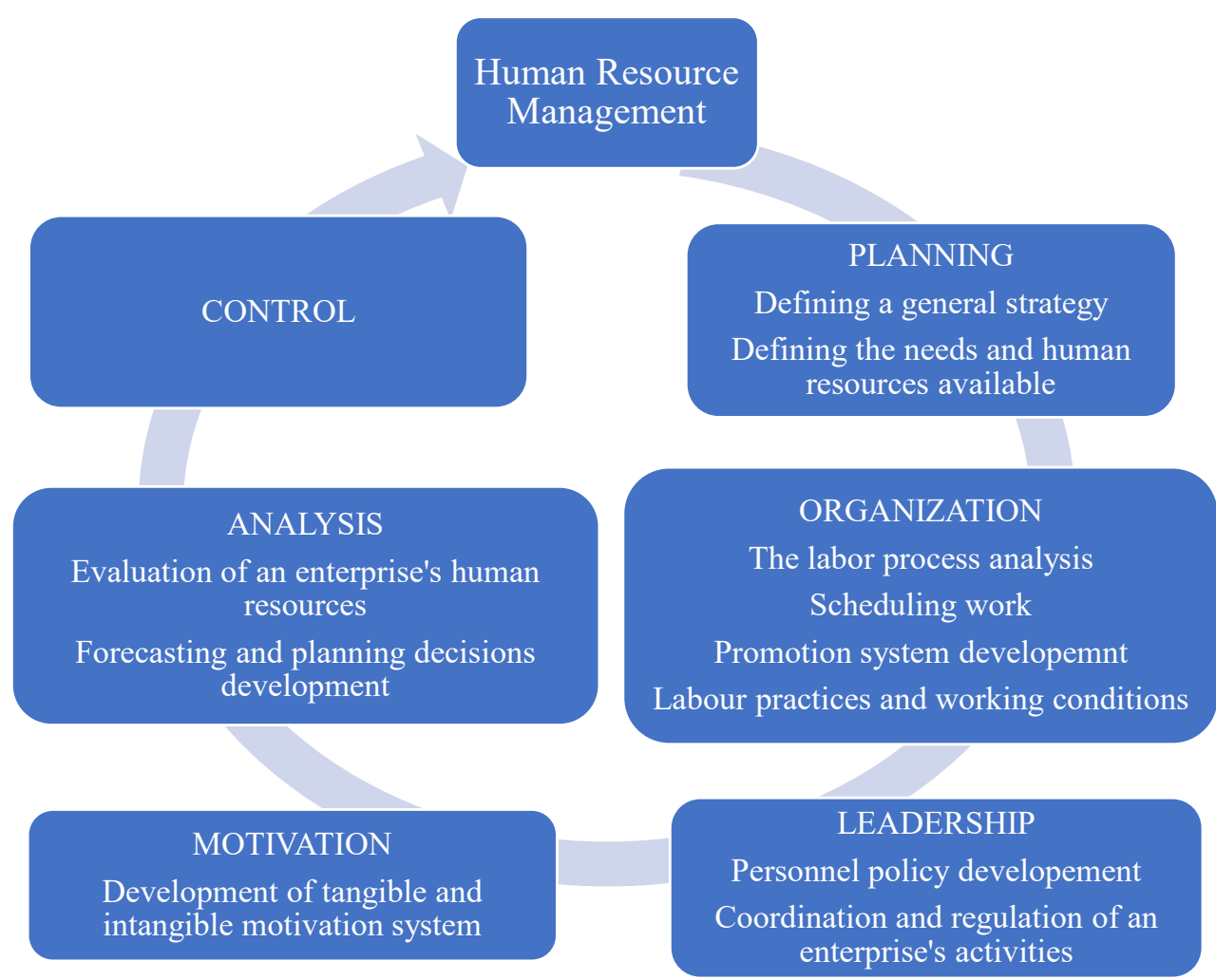

FIGURE 1 The linkages of procedural functions within the human resource management system

Source: developed by the authors, based on the previous researches

- collection and analysis of information on employee's activities, the results of which are used both in the administration activity and in the human resource management processes;

- management of employee's production activities, as the evaluation allows to quickly regulate the labour process and improve its results;

- human resources development, which provides for a worthy motivation choice and professional advancement for workers, and clarification of the further professional training purposes;

- work motivation and evaluation can be used as a powerful impulse to conscious self-evaluation of employees' activities aimed at improving their achievements;
- determining the amount of compensation to pay fairly for work is possible only if objective evaluation of employee's achievements is provided.

In our opinion, human resources evaluation should be provided in order to identify the level of quantitative and qualitative characteristics in terms of defining the state of motivation and efficiency of using human resources by an enterprise.

Human resource evaluation in an enterprise should be provided in clearly defined areas, which are presented in Figure 2.

We recommend making quantitative evaluation of enterprise human resources according to the following indicators, which are presented in Figure 3.

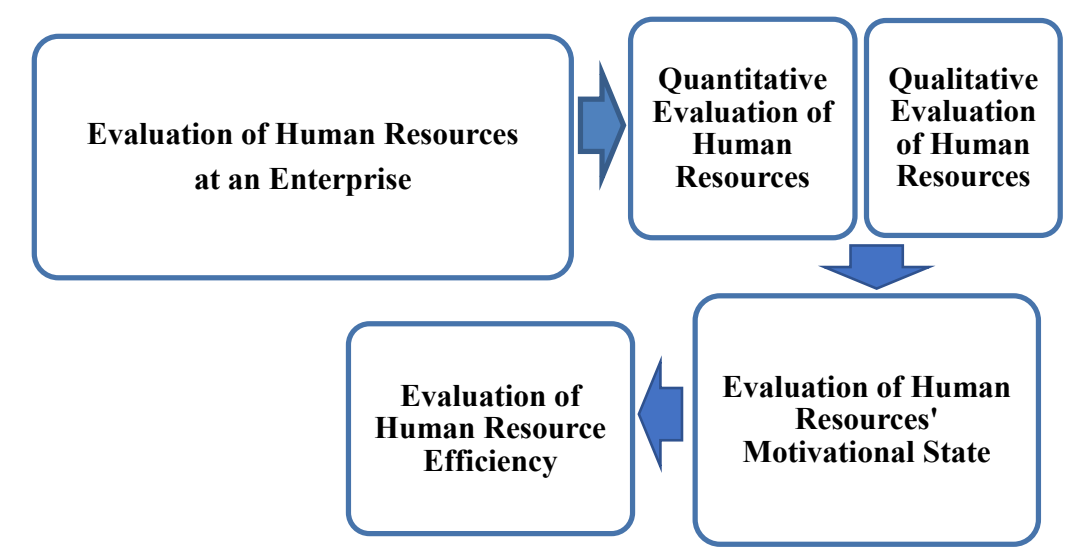

FIGURE 2 Evaluation of enterprise human resources Source: developed by the authors, based on the previous researches 


Quantitative Evaluation
of Human Resources at an Enterprise

FIGURE 3 Quantitative evaluation of human resources of an enterprise Source: developed by the authors, based on the previous researches

\begin{tabular}{|c|}
\hline $\begin{array}{l}\text { Qualitative Evaluation } \\
\text { of Human Resources at an Enterprise }\end{array}$ \\
\hline Age Structure of Human Resources \\
\hline Gender Structure of Human Resources \\
\hline Educational Structure of Human Resources \\
\hline Human Resources Sectoral Education Index \\
\hline Human Resources Structure by Experience \\
\hline Human Resources Index by Length of Service in Relevant Field \\
\hline Human Resources Advanced Training Index \\
\hline Availability Index For Continuous Education System \\
\hline Personnel Stability Index \\
\hline Personnel Reserve Use Efficiency At Filling Vacancies \\
\hline
\end{tabular}

FIGURE 4 Qualitative evaluation of enterprise human resources Source: developed by the authors, based on the previous researches

We recommend making qualitative evaluation of enterprise human resources according to the following indicators, which are presented in Figure 4.

We recommend making evaluation of enterprise human resources' motivational state according to the following indicators, which are presented in Figure 5.

We recommend evaluation of enterprise human resources use according to the following indicators, which are presented in Figure 6.

The human resources evaluation should be based on the following principles [6]:
a) inevitability (mandatory);
b) generalities (evaluate everyone);

c) regularity (evaluation is carried out constantly);

d) comprehensiveness (all parties are subject to evaluation);

e) objectivity (using a sufficiently complete system of indicators to characterize an employee);

f) publicity (broad acquaintance of the staff with the procedure and methods of evaluation, bringing its results to all stakeholders);

g) democracy (public participation, involvement of colleagues and subordinates);

g) effectiveness (mandatory and prompt action after the evaluation).

Evaluation is made in one or another form at each stage of work with human resources [17]: 


Evaluation of Enterprise Human Resources
Motivational State

FIGURE 5 Evaluation of enterprise human resources motivational state Source: developed by the authors, based on the previous researches

\begin{tabular}{|l|}
$\begin{array}{c}\text { Evaluation of Efficiency of Using } \\
\text { Enterprise Human Resources }\end{array}$ \\
\hline Production Volume per Employee \\
\hline Labour Intensity \\
\hline Lost Working Time Coefficient \\
\hline Labour Costs' Share in Total Costs \\
\hline Labor Costs' Share per Productive Hour \\
\hline Human Resources Expenditures' Share in Total Expenditures \\
\hline
\end{tabular}

FIGURE 6 Evaluation of efficiency of using enterprise human resources Source: developed by the authors, based on the previous researches

1) selection of a candidate for a vacant position: the evaluation is necessary to inspect candidate's skills and abilities (both professional and personal) for compliance with the job requirements and firm's corporate culture;

2) during the test (probation period):the purpose is to further assess an employee's proficiency level for compliance with the position and the level of one's adaptation at the enterprise;

3) in the course of current activities: at this stage, the evaluation is aimed at clarifying the plan of an employee's professional and career growth, making decision on bonuses, salaries and wages revision;
4) employee training: it is necessary to test the current employee's knowledge and the need for training; it is desirable to hold a similar procedure after training;

5) transfer to another business unit: it is necessary to test an employee's capabilities to perform new duties;

6) company's succession pipeline: evaluation of employee's professional, and first of all, personal potential;

7) dismissal: at this stage, evaluation is required to identify employee's incompetence, and the reason for dismissal in this case can be certification results only.

Drawbacks of firm human resources evaluation:

Breaking existing ties among the firm employees (if poor organization and incorrect evaluation). 
Benefits of firm human resources evaluation:

1) improving the company's image. Evaluation of human resources is a sign of firm's well-developed personnel policy. Such policy is typical for all stable and solid enterprises. Thus, human resource evaluation is in line with generally accepted international practice;

2) development of staff's corporate sense (spirit);

3) positive impact upon employees' motivation to work and increase the work efficiency;

4) audit and staff development;

5) working out the criteria and optimization of staff reshuffle (rotation) process;

6) optimal distribution of responsibilities between the unit manager and the organization in relation to an employee;

7) removal of hyper-responsibility from the manager (relief of emotional stress);

8) increased organization in human resource work.

Benefits of human resources evaluation for top management:

1) obtaining a tool for personnel decisions;

2) obtaining an instrument for decision-making on salaries and wages differentiation;

3) obtaining an instrument for staff rotation;

4) obtaining understanding of the situation with the firm's staff;
5) identification of the employee pool in order to replace the positions of department managers and a pool for qualified specialists.

\section{Conclusions}

In the view of the mentioned above, the human resources, evaluation is one of the most important components in human resource management. However, the practice of Ukrainian enterprises confirms that the evaluation of human resources is still not regular, and it is not incomplete when the evaluation results are obtained due to use of complex of evaluation indicators. Therefore, for the evaluation of human resources of enterprises it is necessary to apply a flexible comprehensive evaluation of human resources in order to identify the level of quantitative and qualitative characteristics in terms of defining the state of motivation and efficiency of human resources. In our opinion, the evaluation should be implemented with the active involvement of the enterprises' staff themselves. This will lead to providing self-analysis of activities and the development of measures aimed at improving their own work. For business leaders, the results of the human resource evaluation will be a solid basis for decision-making on human resource management.

\section{References}

[1] Armstrong, M. (2004). Human Recourse Management Practice. (8d ed.). Sankt-Petersburg: Piter. (in Russian)

[2] Balabanova, L., \& Sardak O. (2006). Upravlinnia personalom [Human Resource Management]. Kyiv: Professional. (in Ukrainian)

[3] Bratton, J., \& Gold, J. (2003). Human Resource Management: Theory and Practice. London: Palgrave Macmillan.

[4] Cascio, W. (2006). Managing Human Resources: Productivity, Quality of Work Life, Profits. New York: McGraw-Hill/ Irwin.

[5] Chervinsjka, L. (2011). Stymuljuvannja innovacijnoji dijaljnosti personal. The actual problems of regional economy development, 7(1), 287-293. E-source: http://nbuv.gov.ua/UJRN/aprer_2011_7(1)_52 (in Ukrainian)

[6] Chevhanova, V. (2014). System of Estimation of Personnel of Enterprise. Efektyvna ekonomika - Efficient economy, 4. E-source: http://www.economy.nayka.com.ua/?op=1\&z=2906 (in Ukrainian)

[7] Danyliuk, I. (2009). The theoretical aspects of assessing the employment potential of the enterprise. Visnykekonomichnoi nauky Ukrainy, 1, 50-52. (in Ukrainian)

[8] Dessler, G. (2008). A Framerwork for Human Resource Management. New York: Prentice Hall.

[9] Dessler, G. (2007) Fundamentals of Human Resource Management. Moscow: Binom. (in Russian)

[10] Drucker, P. (2011). Management in the 21st Century. Moscow: Williams. (in Russian)

[11] Gavkalova, N., \& Nachar'jan, M. (2017). Classification of concepts of personnel management. Business Inform, 9, 168171. E-source: http://www.business-inform.net/annotated-catalogue/?year=2012\&abstract=2011_09_0\&lang=ua\&s tqa $=44$ (in Ukrainian)

[12] Hrishnova, O., \& Naumova, O. (2005). Otsiniuvannia personalu: suchasni pidkhody do zabezpechennia efektyvnosti [Staff assessment: modern approaches to efficiency]. Formuvannya rynkovoyi ekonomiky - Formation of a Market Economy, 2, 42-50. (in Ukrainian)

[13] Kolot, A. (2002). Motyvacija personalu [Staff Motivation]. Kyiv: Kyivsjkyj nacionaljnyj ekonominyj universytyt. (in Ukrainian)

[14] Kossek, E. (1987). Human resources management innovation. Human Resource Management, 26(1), 71-92. E-source: https://doi.org/10.1002/hrm.3930260105

[15] Koster, F. (2019). Innovative HRM. A review of the literature. Journal of Technology Management and Innovation, 14(2), 97-106. E-source: http://hdl.handle.net/1765/120291

[16] Krushel'nyts'ka, O., \& Mel'nychuk, D. (2005). Upravlinnia personalom [Human Resource Management] (2nd ed). Kyiv: Kondor. (in Ukrainian)

[17] Lebedeva, I., \& Tomashevskay, V. (2018). Approaches to the Evaluation of Personnel as a Component of the Analysis of Human Resources and Technology of its Development. Investyciji: praktyka ta dosvid - Investments: practice and experience, 12, 75-81. E-source: http://www.investplan.com.ua/pdf/12_2018/16.pdf (in Ukrainian)

[18] Lely, Y. (2013). Staff management modern systems and their influence on an enterprise results. Theoretical and practical aspects of economics and intellectual property, 1, 95-98. E-source: http://tpa.pstu.edu/article/view/18976/16655 (in Ukrainian)

[19] Lisak, V. Innovations in a management a personnel foreign and domestic practice. Aghrosvit, 9, 54-60. E-source: http://nbuv.gov.ua/UJRN/agrosvit_2013_9_14 (in Ukrainian) 
[20] Martin, J. (2009). Human Resource Management. London: Sage.

[21] Minbaeva, D., Pedersen, T., Björkman, I., Fey, C., \& Park, H. (2003). MNC knowledge transfer, subsidiary absorptive capacity, and HRM. Journal of International Business Studies, 34(6), 586-599. E-source: https://doi.org/10.1057/ palgrave.jibs. 8400056

[22] Nachar'jan, M., \& Gholovko, D. (2016). The innovations in human resource management as a factor in increasing of the enterprise's competitiveness. Zbirka naukovykh pracj Mizhnarodnoji naukovo-praktychnoji konferenciji. [Collection of scientific works of the International scientifical and practical conference], Ekonomika i menedzhment 2016: perspektyvy integhraciji ta innovacijnogho rozvytku [Economics and management 2016: prospects for integration and innovative development]. Dnipropetrovsk: Bila, K. O., 89-91. (in Ukrainian)

[23] Savchenko, V. (2002). Upravlinnia personalom [Human Resource Management]. Kyiv: Professional. (in Ukrainian)

[24] Schuler, R., \& Jackson, S. (1987). Linking competitive strategies with human resource management practices. Academy of Management Perspectives, 1(3), 207-219. E-source: https://doi.org/10.5465/ame.1987.4275740

[25] Shevchenko, O., \& Yevtushenko, A. (2019). Innovative methods of management of personnel management. Young Scientist, 10(74), 753-757. E-source: https://doi.org/10.32839/2304-5809/2019-10-74-156

[26] Stakhiv, O. (2007). Assessment of staff in the company to encourage employees to training. Ukraina: aspekty pratsi-Ukraine:aspects ofwork,1,29-35.E-source:http://dspace.nbuv.gov.ua/bitstream/handle/123456789/20039/06Stahiv.pdf? sequence $=1$ (in Ukrainian)

[27] Vveinhardt, J., \& Papšienè, P. (2013). The Structure of Human Resources Assessment Process: Conditions for Criteria Formation. Business and Management Research, 2(2), 69-84. E-source: https://doi.org/10.5430/bmr.v2n2p69

[28] Zhykharieva, V., Vlasenko, O., \& Sokolova, M. (2020). The Principles of Innovative Human Resource Management. Modern Economics, 21, 89-94. E-source: https://doi.org/10.31521/modecon.V21(2020)-14 (in Ukrainian) 